\title{
Poster Presentation as A Tool to Assess Students' Academic Speaking Performance: Teachers and Students' Perspectives
}

\author{
Renny Tarigan, \\ Listyani \\ Universitas Kristen Satya Wacana (UKSW) \\ Jl. Kartini 15-17 Salatiga 50711 \\ listyani.listyani@,uksw.edu \\ Article History: Submitted on 18 ${ }^{\text {th }}$ December 2020; Accepted on $6^{\text {th }}$ April 2021; \\ Published on $30^{\text {th }}$ June 2021
}

\begin{abstract}
A poster presentation is a way to share or inform research data and information in oral communication. Through poster presentation, the presenters will be able to present the data easily. In education, poster presentation is always used for the research seminar and the conference. For the English-speaking students, they use a poster presentation to learn English and use English as an academic speaker. This is why the Academic Speaking classes at an English Language Education Program (ELEP), in a private university in Central Java, Indonesia used the poster presentation as the final project to assess students' performance. The study was conducted at the Faculty of Language and Arts, at a private university in Central Java, Indonesia. The study aims to see how the teachers and students' perceptions about poster presentation and how it can increase the students' academic speaking performance. The research participants were two of Academic Speaking class' lecturers and two students of batch 2016. They were interviewed using an audio recording and also the interview protocol. Based on the interview, there are some different opinions about using poster presentations in Academic Speaking class. Overall, the results found that poster presentation, a form of speaking skill assessment, could increase the students' academic speaking performance, such as eye contact, gesture, fluency, pronunciation, vocabulary, and knowledge.
\end{abstract}

Keywords: poster, presentation, assess, academic speaking 


\section{INTRODUCTION}

"Language is first and foremost a spoken and not a written entity" (Hussain, 2017). The statement seems to be true that humans spoke to each other long before humans invented writing. Speaking is one among other aspects of language. When we learn a language (English), four skills should be mastered: listening, speaking, writing, and reading. Since English is an international language, people will communicate with people from other countries with English. Therefore, learning to speak English becomes an essential skill. Khamkhien (2010), as cited by Al-Roud (2016), argued that "Speaking skill is the most important in the second language" (p.2).

Asrida (2014) defined speaking as the information sharing between the speaker and the listener in any circumstance. This is in line with Bahrani and Soltani's (2012) opinion that the goal of teaching speaking is communication efficiency. Nadia and Yansyah (2018) also claimed that teaching speaking is a demanding task because it does not deal with language ability only, but with psychological problems like self-confidence, anxiety, and other problems.

One of the speaking classes to teach is Academic Speaking class. In the Academic Speaking class, the language used differs from the language that is often used every day. According to the topic and issues, the language is academic, which means speaking according to the students' context. Many activities have been done in Academic Speaking class lately to train the students' academic language, such as speech, dialogue, and presentation.

As an illustration is that the students have to do an oral presentation in the classroom where the students talk independently in front of the audience. They choose their topic. In this project, the students should present the topic with excellent academic language, and they should have clear pronunciation, grammar, appropriate vocabulary, and fluency. In presenting the topics, the students also need to pay attention to their appearance or performance, where they should be able to dress well, use a good gesture, and demonstrate in explaining. The students also need tools to facilitate their presentation by using the appropriate visual aid, such as a PowerPoint slide and poster. Hartatik and Rohmah (2016) asserted that pictures and colorful posters could add attractiveness and atmosphere in the language classroom.

Nowadays, the PowerPoint slides and posters are standard tools that the students use in doing their oral presentations. In an Academic Speaking class of a private university in Central Java, Indonesia, the students do the poster presentation as a final project to meet the requirement of the class. In our experience in this project, students need to prepare the poster creatively, plan the tremendous and controversial topic, and prepare the poster's structure (beginning, middle, and conclusion). The presenter should 
prepare their language with clear pronunciation, use the academic vocabulary, talk in a neutral way, not biased even though the topic is controversial, get dressed well, and prepare their physical for speaking in front of many people. In this project, the students are highly demanded to be able to speak academically in performance. Being an academic speaker with perfect performance is emphasized in the academic speaking class. That's why the students need to consider their pronunciation, grammar, vocabulary, fluency, background knowledge, comprehension, gesture, and outfit.

However, speaking for learners of a foreign language is that they do not have confidence in talking because they feel afraid to make mistakes. According to Dil (2009), as cited by Al-Roud (2016) wrote in his study that "anxiety and willingness are the biggest obstacles for the EFL students while speaking in the classroom" (p. 3). The students seem afraid to start to speak because they always think negative thoughts before talking. It is not a motivating situation where the students do not feel comfortable with the situation. It is because they always think negatively in their mind.

The other problems of academic speaking are found by Lin (2014) as cited by Al-Roud (2016). In his study, he found 213 students as the samples, the biggest problem in "speaking is a mental presentation, being anxious in talking in front of many audiences" (p. 3). The other is guessing word meaning, grasping the main idea, using slang or idioms, and identifying the sentence structure.

According to Adeyleh (2013), as cited by Al-Roud (2016), students' most significant problem in speaking is terrible pronunciation. The students change the sound of the vocabulary when they speak to a more regional language. According to the above problems, some students are still in low academic speaking proficiency. The same problem may happen for the students in the English Department. Even though they can speak fluently, they are unnecessarily fluent at academic speaking performance. In this problem, the students seem to need some solutions to solve their academic speaking performance problem.

There are many ways also that the teachers use to train the students so far, such as what has explained above in Academic Speaking class, the teachers use speech, discussion, debate, and poster presentation as the activity in training their academic speaking performance. However, this study investigated the use of poster presentation to better improve the students' academic speaking performance in Academic Speaking class. Since the Academic Speaking class uses the poster presentation as the final and biggest project in this class, the main focus of this research is to see the teachers' and students' perceptions about poster presentation. It can increase students' academic speaking performance, including pronunciation, grammar, vocabulary, fluency, background knowledge, comprehension, gesture, and outfit. Oceanography Society (2005) claimed that a poster must convey the presenter's basic message within two to three minutes. At best, 
it should also engage the viewers' interest so that they are willing to invest more of their time in the presenter's work.

There is only one question addressed in this study, that is:

How can the poster presentation be used to increase the students' academic speaking performance according to the teachers and students' perspectives?

The aim of this study is that we want to see the functions of poster presentation in increasing the students' academic speaking performance. How poster presentation can increase pronunciation, grammar, vocabulary, fluency, background knowledge, comprehension, and gesture.

In this study, the point that the study emphasizes is about poster presentation, which is a part of AVA (audio-visual aid). It is like a tool in teaching English as teachers' strategies to make the lesson effective and exciting. In the study, the point is not on AVA use for teaching but the use of AVA for the students. The students learn to present as a teacher and as a learner at the same time because the students should learn to prepare their presentation using the AVA and learn to teach while presenting the topic through the AVA. Hopefully, this study will be helpful for the teachers of academic speaking class, where they can use poster presentations like the way found in this study to increase the students' academic speaking proficiency.

A poster presentation is a tool to share or communicate about the data of research and information on oral communication style. The data can be a picture and graphics data package displayed on an exciting look where it means as a poster. The poster presentation is usually done by presenting the data in front of a large group (audience). In this way, the audience can also ask and comment on the poster. Beilenson (2004), as cited by Miller (2006: 313), stated that "a poster is a dialogue between the presenter and the viewers" (p. 313). Another opinion is from Akister, Bannom and Lock (2000), who explained in their journal that the poster is a visual presentation with a small work and an exciting viewing that can directly discuss audience and presenter. The same idea is from Jennings and O'Neill (2012), "Poster presentation can allow for question and answer sessions, and the exchange of ideas and information regarding research" (p.3).

In education, poster presentations are used for research seminars and conferences. Using a poster will usually help the presenter to explain the information to be conveyed. As an example, Maugh (1974) found in his study, as cited by Hess, Tosney, and Liegel (2009), "The poster session is a new look at scientific meetings" (p. 1). Sorensen and Boland (1991) and Fowles (1992), as cited by Berry and Houstan (1995) said that the students use the poster presentation to report their research investigations for nurse education. For mathematics students, poster presentation is the way to communicate with other students and as an activity to take an assessment (Berry and Houstan, 1995). From Arief's (2020) research, it was also found that posters could be effective media to teach speaking to media students. 
For English-speaking students, poster presentation is usually used to learn a language of how the students can practice in speaking. Zerin and Khan (2013, p.129) state that poster presentation is a tool to demonstrate their understanding and communicate in English speaking. More specifically, English-speaking students use poster presentations to train them talking and thinking more critically. Poster presentations can also be a way to explain the results of research. The result of the research is incorporated into an exciting poster. The posters are an effective method of presenting academically.

According to Wilson \& Brooks (2014), using oral presentation (It is also a poster presentation) in the language classroom is beneficial because it can improve the students' communication skills (writing, speaking, listening, and listening) and motivate the students to learn English. Through the poster presentation, the students have the opportunities to practice talking and critical thinking. In other words, presenting the topic in front of audiences trains them to speak and write while preparing the poster. On another side, the audience listens to the presenter and reads while seeing the performance and the poster. This is called student-centered and it is good for the students to practice by themselves in learning the language.

According to Daniel (1992), as cited by Berry and Houstan (1995), five reasons suggest the students use poster presentation, it is because poster presentation is a great way to increase the students' communication skill, an assessment that is done by the students themselves, to encourage the students' skill to analyze the topic, give the students opportunity to learn with their friends, and to expand the positive attitude of the students. In addition, Zerin and Khan (2013) found that the students enjoyed the poster presentation because doing poster presentation makes them creative in learning language, have a comfortable situation between the students and have a chance to practice using language. The same idea comes from Ziscovic (2014). He claims that using oral presentation makes the student think broadly and trains strategic thinking. It means that oral communication improves the way of their thinking.

Niemantsverdriet (2000) added that a poster is considered successful if it conveys a clear message to the audience and generates valuable comments to the presenter. Therefore, the poster needs to be crystal clear about the objectives, approach, main results and major conclusions of the work. Rahmadevi (2012) also reminded us that pictures in the posters and the colors could attract students' interest.

For the disadvantages of poster presentation, Sisak (1997) argues that the students feel difficulty doing poster presentations. It is because they cannot find a suitable topic with suitable references. Another disadvantage of the poster presentation is that the students often present the idea or topic with a book source, but it doesn't benefit from increasing their thinking on problem-solving. 
The same idea comes from Hess, Tosney, and Liegel (2009), they found in their study that some presenters are not interested in doing poster presentation which impact on the quality of their poster, such as the visualization of poster are not attractive, there is much text, the poster is not explicit and the structure is not organized. Academic speaking performance is about presenting a topic academically. The objective of academic speaking, as explained by McEvedy (1986), cited by Mcpherson (1995) is to show how to plan, of research materials in a formal presentation, to prepare the written material and oral version in the same way, to prepare and use appropriate visual aid and to take part in seminars.

According to Zerin \& Khan (2013), from their survey, 85 to $95 \%$ of 50 students think that using poster presentation is a benefit for them in increasing their speaking proficiency. How can it improve their academic speaking skill fluency? The students like to present the poster by showing the picture with many attractive points to encourage them. They feel proud of making a poster and ready when there is some difficult task in the future. Another thing of how a poster can increase the students' academic speaking skills is by training the students to speak more while presenting all the points. Before they do the poster presentation, they will prepare the topic, poster, and speech. Indeed, while preparing the speech they will think about good grammar, academic language, and explicit language. So poster presentations can improve the students' academic speaking fluency. There is also a rubric where they can evaluate their performance by themselves, such as fluency, accuracy, grammar, vocabularies and knowledge about the topic.

A summary of this literature review shows that poster presentation is the tool to communicate between presenter and audience. In many cases, the presenters use the poster presentation to make the research easy to explain. Most people use poster presentations to explain their result of observation and as a proposal for the work in a company. In education, the students use the poster presentation to tell about research.

For English language students, they use the poster presentation as an assessment to assess and train the students' academic speaking skill. The students always use the poster as the last project and as a test for the students to complete the class requirements. The point is the students that should prepare themselves to be good academic presenters. Good academic presenters mean they should have good fluency, accuracy, grammar, vocabulary, and knowledge about the topic.

There have been some previous studies done dealing with poster presentation. Wahyuni, Mukhaiyar, and Kusni (2013, p.22) claimed that posters could be one of the techniques modified by Thornbury (2005) called "Inside/ Outside circle technique". These techniques, onion, poster carousel, and headlines \& art gallery, were adequate to improve students' speaking ability. A similar study was also conducted by Putri (2013). Using a poster carousel, students could improve their speaking ability. Öztürk (2017) also researched whether the use of poster presentations facilitates 
learning when students try to put theoretical ELT knowledge into practice. Öztürk found those poster presentations could help learners work collaboratively in groups. They could also overcome their anxiety and gain more self-confidence while doing the presentation. In addition, poster presentations could improve creativity, promoted learner autonomy, and inspired learners for their future teaching career.

Another research study was also conducted by Pamela (2019) on 73 eleven graders of SMAN 1 Pandeglang. Her experimental research found that students speaking analytical expository text using poster presentation achieved better performance than those who did not use it. Ulva (2018) also conducted a study in this matter. Her research purpose was to investigate the improvement of students' English speaking ability by using poster media. The second purpose was to figure out the students' opinions on using poster media to teach English. Data derived from questionnaires, interviews, and observation showed that the speaking ability of students' MTsN 2 Banda Aceh increased due to Poster Media.

Yavani \& Anani's study (2018) on the effectiveness of posters and video in assisting students when speaking found that using posters could significantly improve the students' speaking ability in the English teaching. In line with Yavani and Anani, Basri (2017) also researched the use of posters. Her research was to answer the question about the effectiveness of posters to improve the eleventh graders' speaking ability at MA Pesantren Modern Datuk Sulaiman Putri Palopo. The research found that the educational poster media were effective in improving the eleventh graders' speaking ability.

\section{METHOD}

This study is qualitative. Qualitative study analyses how the experiences and opinions of the teachers and the students in using poster presentation and how it can increase the students' academic speaking performance. It is for getting in-depth information about the poster presentation in academic speaking class and increasing the students' academic speaking skill.

The study was done in an Academic Speaking Class, which is the last speaking class at the English department of a private university in Central Java, Indonesia. This class is different from the other speaking classes (such as speaking for social purpose and argumentative class). This study was done in the Short Semester of the 2017-2018 Academic year. In this study, the participants were three students and three teachers of Academic Speaking class. In this case, three students were 2016 years and have experiences taking the class of academic speaking. The instruments in this study are the list questions (Interview protocol), and video recording using a mobile phone or audio recording. 
In this research, the data collection method was done through interviews. In this method, the researchers and the participants (the teachers and the students) had dialogues, asking and answering questions one by one with each of the students and teachers. While doing the interview, the researchers took the videos and transcribed all the conversation with the complete answers and questions. After that, the interviews were transcribed. Themes were finally drawn, and discussed in depth.

\section{FINDINGS AND DISCUSSION}

Based on the interviews, there were some findings of using the poster presentation in Academic Speaking class and how it can increase students' academic speaking performance. Based on the findings, both students and the teachers have different perceptions about using poster presentations in Academic Speaking class that can increase the students' academic speaking performance. Here is the explanation about the students and teachers' perceptions of using poster presentation in Academic Speaking class.

\section{Teachers' Perceptions on the Use of Poster Presentation}

In this section, the two teachers have the same perceptions about using a poster presentation and how it can increase students' academic speaking performance. In the interview, they said that the previous way had been the best way for them to present the poster in the actual context. The previous way in the academic class was like presentation in the public area and working in groups with three members. The groups from four classes of Academic Speaking join into one big room in the hotel. There, they made the poster presentation with four sections. In each section, one of the members became a presenter to present the poster, the others members of the group should go around to the other group poster presentation to be the audience for another group presentation. In other words, the teachers wanted to make the poster presentation project in the Academic Speaking class as the project to train the students to feel the authentic atmosphere in the public areas.

The teacher A said that in that concept on the F floor and the hotel setting is the best way to present the poster. It is because the students can feel the authentic atmosphere which means public area.

\section{Excerpt 1}

"The concept to do the presentation in the F building has been well because we had various audiences. The setting of the hotel as the public area also made the atmosphere." (Teacher A, interviewed on May $22^{\text {nd }}, 2018$ ) 
The Academic Speaking students will get challenges to prepare the material well through the previous concept or setting. It starts with collecting the data to make the exciting poster. It certainly can increase the students' knowledge as the academic speakers. Through the previous way, it will train them to improve their knowledge.

\section{Excerpt 2 \\ "In that way, students have to prepare well before presenting the poster. Before doing the presentation, they should provide the materials such as reading books, Google, and also do mini research (interview). Through that way, they will enrich the information. Because if you need to present the poster, you need to express your opinion with enough data and information, without reliable information, people will have nothing from the presentation. So, preparation is most important to prepare data to present." (Teacher A, interviewed on May 22nd, 2018)}

Since they prepare the poster, they should organize the data starting with abstract, the background of the problem, findings, conclusions and the suggestions. In that way, it will help the audience follow the information. The enough data and complete information should be arranged into the best format in the poster presentation. In this case, the students will experience increased knowledge while preparing the poster re-arranges the data to be the best format.

\section{Excerpt 3}

"When they had done the preparation well, of course they would arrange the organization of the data. It also includes the preparation and part of making the poster. However, we need to rearrange the data, therefore the audience can understand the information. So, rearranging the idea in the poster format and investigation the data is in the poster. If the format and the organization have been okay, it would belp the students too." (Teacher A, interviewed on May $22^{\text {nd }}, 2018$ )

After doing the poster preparation starting from finding enough data to re-arrange the data in the best format, the students also need to practice first with their friends or in the small group to evaluate. They also can get feedback from the teachers through the lesson. The rehearsal is also an important point before the presentation. Through this process, the students will get improvement in their language, eye contact and appropriate movement. 


\section{Excerpt 4 \\ "After data was arranged well, next is the time for presenting. But before that, they need to practice. It can be in the small group, or within the class, peer evaluating from their friends, and also teachers' input. So it is like a rehearsal. They will practice speaking as academic presenters, use eye contact, and movement." (Teacher A, interviewed on May 22 $2^{\text {nd }}, 2018$ )}

The same idea comes from Amel (2014) that poster session in the classroom aims "to develop the students' fluency in English, improve the vocabulary in the particular area, to see how English is used as communication, to increase the research, reading and presentation skills" ( $p$. 3543). In that way, the students can help also in presenting material through the poster. The point is that the students can develop their academic speaking performance.

Besides that, teacher B has the same idea with teacher A where they agree to use the poster presentation like the previous concept. The reason for teacher B is because it trains the students to be able to perform similarly to the academic speaker at the international conference.

\section{Excerpt 5 \\ "We choose the poster presentation just like the previous concept, it is not only to practice speaking but the students can practice to present such as at an international conference." (Teacher B, Interviewed on May $\left.22^{\text {nd }}, 2018\right)$}

Through the previous concept, the students will also be able to learn in the group. They can prepare the material in the group. Sharing with friends can also improve academic speaking performance such as speaking, critical thinking, and other soft skills. Conyers (2001), Jarvis and Cain (2003), as cited by Howard (n.d) explained on his paper that "the poster provide a stimulating assessment tool, allowing for creativity and leading the students' skill to 'integrate critical thinking and communication skills within the context of diverse subject and content areas".

Excerpt 6

"Using the poster presentation is not only to improve the speaking skill, but it is like collaborative learning, learning with group friends. When they should be more critical thinking, they also prepare the topic. Though this way, the poster presentation has many soft skills which are prepared." (Teacher $\mathrm{B}$, interviewed on May $22^{\text {nd }}, 2018$ )

Both teachers have similar perceptions about the use of poster presentation in Academic Speaking class. The point is that poster 
presentations should be in the authentic atmosphere such as the hotel or $\mathrm{F}$ floor with the many varieties of the audience. It should also be done as the poster in the group with three or four members for collaborative learning. Next, they made the concept similar to the international conference. In this way, teachers A and B believe that the students' academic speaking skill will improve while doing the process starting from preparing the data to the day of the presentation. The skills that will improve are the students' speaking, movement, eye contact, knowledge, and critical thinking.

\section{Students' Perceptions on the Use of Poster Presentation}

Two students were interviewed about their perception of the use of poster presentation in the Academic Speaking class, increasing the students' academic speaking skills. As overall, the students have different perceptions about the use of poster presentation. Here is the explanation of their every perception.

Students A agreed to use the poster presentation like the previous concept to work in the group. It is because they can learn with each other with their friends. However, she explains that the poster presentation should be used many times in the class. In that way, the students and the teachers can feel and see the improvement. Such as Tanner \& Chapman (2012) they explained in their study that the critical advantages when the students do poster presentations more than one will lead them to increase their skills through repetition.

\section{Excerpt 7 \\ "We can develop our academic speaking skill, and public speaking and delivery if we do poster presentations a lot in the classroom. When we do it in the classroom, it can make us feel comfortable and confident. It can be done one or two times for a week. After that, the teachers can see the improvement." (Student A, interviewed on May $11^{\text {th }}, 2018$ )}

The fluency and pronunciation are the skills that improved through this poster presentation project. It is because the students are required to speak in the all-time of the project. Through this project, all levels of the students can learn together to learn from each other to improve their speaking. Therefore, the students can help them to speak fluently in English by this poster presentation project.

Excerpt 8
"So, I really think that by presenting this poster presentation we
can practice our pronunciation and also our fluency. Although not
all the students have similar capability no matter whatever they are
still in the beginner, average, and the higher level. We can learn

Poster Presentation as A Tool:...

Renny Tarigan, Listyani

DOI: https://doi.org/10.26714/lensa.11.1.2021.1-16 
through the poster presentation to belp our fluency." (Student A, interviewed on May $11^{\text {th, }}$ 2018)

Through the poster presentation, the students will also get the better knowledge. They are required to find some information through doing research, reading the book or browsing. In this way, they will get improvement in their knowledge.

Excerpt 9

"We have to do the same research, to Google, we have to Google about something that is to make our world a better world. It really helps the students to enhance, to stimulate our knowledge." (Student A, interviewed on May $11^{\text {th }}, 2018$ )

As the student's A perception is, the used poster presentation in the classroom is essential. It gives positive impacts to the students. They will get improvement in their academic speaking skill, such as pronunciation, fluency and their knowledge.

Another student interviewed was Student B. Student B perceived that poster presentation should look like a seminar concept. Poster presentations should be done like a big seminar where there are many variations of themes to catch the audience's attention. In this concept, there is also an activity where the students and the audience can debate. The student B believes that through this way the students will be helped in increasing their academic speaking performance because the activity requires them to critique and debate.

Excerpt 10

"Maybe the presentation should have more variation to catch the audience's attention. The poster presentation should make a difference. Another way, it can be a big seminar. There is an activity where the presenter, critics. So, there is a debate which is useful for the students." (Student B, interviewed on May 9 ${ }^{\text {th }}, 2018$ )

The poster presentation is also good for the students to improve their pronunciation and knowledge because of the mini-research. Doing this project makes them practice the pronunciation and knowledge.

\section{Excerpt 11}

"The group poster presentation is also good because it helps the pronunciation, vocabulary and the knowledge. They also have to do mini research to improve their knowledge." (Student B, interviewed on May $9^{\text {th }}, 2018$ ) 
The students' perceptions summarize that the student A's perception is that using presentation posters should be done many times. It aims to see how poster presentation can train students to see their enhanced skills in academic speaking. When the students have a poster presentation project many times, it will certainly challenge them to do a lot of preparations and practices. In that way, it will be able to improve the students' academic speaking performance.

Student B's perception is that poster presentation should be used in the form of a large seminar. Variations of the theme for each group should also be multiplied and varied in each group to attract the audience's attention. In this case, student B believes that poster presentation through the big seminar will improve their knowledge and pronunciation because they will do a mini-research.

\section{CONCLUSION}

This study aims to find out how the use of poster presentation in Academic speaking class and how those ways can increase the students' academic speaking performance. According to the result finding and discussion, there are different opinions from each teacher and student about using the poster presentation in Academic speaking class that can increase the students' Academic Speaking performance.

Based on Teacher A's perception, the poster presentation should be in the authentic atmosphere. Based on Teacher B's perception, the concept or the setting of the poster presentation should look like an International Conference. The students should work in the group of three or four members to collaborate. It is to increase the students' pronunciation and vocabulary. When the feelings and atmosphere look natural and like an international conference, students can practice improving their abilities such as eye contact, movement, fluency, knowledge, and gesture during the poster presentation. Before doing the poster presentation, the students will get peer evaluating and also teachers' input.

Student A's perception about using the poster presentation in Academic Speaking should be done many times in the classroom during the first semester. It can be done once in two weeks. It is to see the improvement. The more they practice in the poster presentation will improve their academic speaking performance. Based on student B's perception, poster presentation should be made like a big seminar with the variations theme to get the audience's attention.

According to the result findings and the discussion, here are some suggestions for using poster presentations to increase the students' academic speaking performance. First, the use of poster presentation should be done in much time. It can be done once in two weeks. It is to practice speaking as the academic speaker and improve the students' academic speaking performance. Second, group poster presentations are needed in 
Academic Speaking class because the students can learn from each other through the discussion time. Third, the teachers should prepare many variations of themes for each group to catch the audience's attention. Fourth, the setting of the poster presentation can be in the actual setting or public areas, it can also be in the classroom. Fifth, the concept of the poster presentation can look like an international conference. It can look like a big seminar.

\section{REFERENCES}

Akister, J., Bannon, A., \& Mullender-Lock, H. (2000). Poster presentations in social work education assessment: a case study. Innovations in Education and Training International, 37(3), 229-233. DOI: 10.1080/13558000050138461

Al- Roud, A, A. (2016). Problems of English speaking skill that university students encounter from their perspectives. British Journal of Education, Society \& Behavioural Science, 18(3), 1-9.

Amel, B. (2014). Students' Awareness of the Use of Poster, PowerPoint and Animated Video Presentations: A Case Study of Third Year Students of the Department of English of Batna University. International Journal of Information and Communication Engineering, 8(11), 2542-3546.

Arief, M. H. (2020). The implementation of poster presentation project in teaching speaking of descriptive text for vocational school. RETAIN, 8(1), 7-15. Retrieved from https://core.ac.uk/download/pdf/287306739.pdf

Asrida, D. (2014). Communicative activities of teaching speaking for the students Ta'dib, 17(1), 60-65. Retrieved from http://ecampus.iainbatusangkar.ac.id/ojs/index.php/takdib/articl e/download/259/256

Basri, Y.H. (2017). Upgrading students' speaking skill by using poster at the eleventh grade of MA Pesantren Modern Datok Sulaiman Putri Palopo. A Thesis. IAIN Palopo, South Sulawesi, Indonesia. Retrieved from http://repository.iainpalopo.ac.id/id/eprint/2035/1/Yuyun\%20R ahayu $\% 20$ Basri.pdf

Berry, J \& Houston, K. (1995). Students using posters as a means of communication and assessment. Retrieved from https://eric.ed.gov/?id=EJ512633

Hartatik, S.F. \& Rohmah, T.H. (2016). Investigating the Students' Views on the Authentic Materials Used in Basic Speaking Class. Indonesian Journal of English Language Teaching and Applied Linguistics, 1(1). Retrieved from http://ijeltal.org/index.php/ijeltal/article/view/4

Hess, G., Tosney, K., \&Leigel, L. (2009). Creating effective poster presentations. AMEE Guide No 40. Dundee: Association for Medical Education in Europe (AMEE). Retrieved from 
https://amee.org/getattachment/Conferences/AMEE2019/Abstracts/eG40 Electronic.pdf

Howard, C. (2015). The Role of Posters as a means of Summative Assessment. Retrieved from June $30^{\text {th }}, 2018$. University of Worcester. Retrieved from http://eprints.worc.ac.uk/3688/

Hussain, S. (2017). Teaching Speaking Skills in Communication Classroom. International Journal of Media, Journalism and Mass Communications (IJMJMC), 3(3), 14-21. Retrieved from https://www.arcjournals.org/pdfs/ijmjmc/v3-i3/3.pdf

Jennings, D., \& O’Neill, G. (2012). The use of posters for assessment: A guide for staff. UCD teaching and learning. Retrieved from: https://cpb-euw2.wpmucdn.com/blogs.brighton.ac.uk/dist/7/3977/files/2018/ 03/UCDTLA0039-1m0c51o.pdf

McPherson, K. (n.d). Developing speaking skills in academic contexts. Retrieved from bttp:/ / cunningham.acer.edu.au/inted/ eaconf95/mcpherson.pdf

Miller, J, E. (2007). Preparing and presenting effective research posters. HSR: Health Services Research, 42(1), 311-328. DOI: 10.1111/j.14756773.2006.00588.x

Nadia, H. \& Yansyah (2018). The effect of public speaking training on students' speaking anxiety and skill. Proceedings of the $65^{\text {th }}$ TEFLIN International Conference. (pp. 227-232). Makassar, Indonesia. Retrieved from https://ojs.unm.ac.id/teflin65/article/download/6276/3615

Niemantsverdriet, J.W. (2000). How to give successful oral and poster presentations. Retrieved

from http://www.pitt.edu/ gveser/Ethics/HowToGiveAPresentation. pdf

The Oceanography Society. (2005). Scientifically speaking. Retrieved from https://www.tos.org/pdfs/sci speaking.pdf

Öztürk, Ö. (2017). Using poster presentations to facilitate preservice EFL teachers. International Journal of Language Academy, 5(4), 401-415. Retrieved from https://pdfs.semanticscholar.org/3823/3b9c083bde9790c5dc85bc c4d5c5adc0821e.pdf

Pamela, P.B.P. (2019). The influence of using poster presentation towards students speaking ability (Quasi experimental research at the eleven grade of SMAN 1 Pandeglang in the academic year of 2018/2019). A Thesis. University of Sultan Maulana Banten, Indonesia. Retrieved from http://repository.uinbanten.ac.id/4089/1/SKRIPSI.pdf

Putri, M.A. (2013). The effect of using the poster carousel technique toward speaking ability of the second year students at State Senior High School 3 Mandau Bengkalis Regency. A Thesis. UIN SUSKA Riau. Retrieved from http://repository.uin-suska.ac.id/9719/1/2013 201398PBI.pdf 
Rahmadevi, Y. (2012). Using everyday life posters in teaching speaking to elementary school students. Abstract. retrieved from http://repository.unp.ac.id/3056/1/3 A YUMARCHELY RAH MADEVI 01589 6597 2012.pdf

Sisak, M, E. (1997). Poster sessions as a learning technique. Journal of Chemical Education, 74(9), 1064-1066. Retrieved from bttps://pubs.acs.org/doi/abs/10.1021/ed074p1065.2

Tanner, P., \& Chapman, J. (2012). Poster presentation speak for themselves. The language Teachers, 36(2), 15-19. Retrieved from https://jalt-publications.org/sites/default/files/pdfarticle/36.3 art 3.pdf on August 15, 2020.

Ulva, S. (2019). The use of poster media in improving students' speaking ability (A case study at MTSN 2 Banda Aceh). A Thesis. Ar-Raniry State Islamic University, Darussalam, Banda Aceh, Indonesia. Retrieved from https://repository.arraniry.ac.id/id/eprint/9224/1/SKRIPSI\%20FULL.pdf

Yavani, Z. and Anani, N. (2018). The effectiveness of poster vs video in speaking skill of EFL learners. Jurnal Tadris Bahasa Inggris, 11(1), 133-147. https://pdfs.semanticscholar.org/44d4/52cde8c8d3cf234e802094 490ef164d40387.pdf

Wahyuni, D.S., Mukhaiyar, \& Kusni. (2013). Improving students' speaking skill by using Inside-Outside Circle Technique (at English for Teen Level 5, LBPP LIA, Pekanbaru). Journal English Language Teaching(ELT), 1(2), 17-29. Retrieved from http://ejournal.unp.ac.id/index.php/elt/article/download/4556/ $\underline{3601}$

Wilson, J., \& Brooks, D. (2014). Teaching presentation: Improving oral output with more structure. Proceedings of CLaSIC, 2014, 512-521.

Zerin, S. \&Khan, S., A. (2013). Poster- a visual stimulus for active learning. GSTF International Journal of Law and Social Sciences (JLSS), 3(1), 129134.

Živković, S. (2014). The importance of oral presentations for university students. Mediterranean Journal of Social Sciences, 5(19), 468-475. 